\title{
RESEARCH
}

Open Access

\section{Role of context on propensity of women to own business}

\author{
Ángeles Muñoz-Fernández ${ }^{1}$, Rashmi Assudani ${ }^{2^{*}}$ (D) and Imane Khayat ${ }^{2}$
}

\author{
*Correspondence: assudanir@xavier. \\ edu \\ ${ }^{2}$ Department of Management and \\ Entrepreneurship, Williams College \\ of Business, Xavier University, 3800 \\ Victory Parkway, Cincinnati, $\mathrm{OH}$ \\ 45207, USA \\ Full list of author information is \\ available at the end of the article
}

\begin{abstract}
The obstacles to, influences on, and impact of women's business ownership have been studied for the researchers, offering a substantial knowledge about the female entrepreneurs and their businesses. However, the vast majority of research about women entrepreneurs is still very western-oriented, and more studies are needed based on international data. This investigation examines the extent to which a set of social and firm factors influences women's decisions to start and grow their own businesses. It includes 59 countries and takes into account their stages of economic development. Findings show that the level of a country's development has an impact on how social and firm factors affect women's decisions to become engaged in business. Findings also show that women's education levels are independent of their country's level of economic development, in terms of its impact on their entrepreneurship. Recommendations are provided to promote women's entrepreneurship and support them to reach their potential.
\end{abstract}

Keywords: Women's entrepreneurship, Economic growth, Corruption, Access to education, Age dependency ratio, Firm size

\section{Introduction}

Despite its more recent origins, research on women's entrepreneurship has come a long way in a very short time, surpassing many of the developmental milestones in the broader field of entrepreneurship (Jennings \& Brush, 2013). Research has explored issues like women's motivations for starting businesses, the survival and profitability of women-owned businesses, decisions about business growth, or work-family balance (Yousafzai, Saeed, \& Muffatto, 2015). It is also noteworthy that women business owners comprise one of the world's fastest growing entrepreneurial populations (Brush, Carter, Gatewood, Greene, \& Hart, 2006), accounting for up to one-third of all businesses operating in the formal economy worldwide (International Labour Organization, 2016), and playing a substantial role in economic growth at both the community and country level (Guillén, 2014; Terjesen \& Amorós, 2010). Female entrepreneurs make positive contributions to GNP, job creation, innovation, and global social welfare (Brush \& Cooper, 2012), which policymakers have acknowledged (Bullough, Renko, \& Abdelzaher, 2017).

One area in this field that remains understudied is the role of context on women entrepreneurship (Brush \& Cooper, 2012; Welter \& Smallbone, 2011). The phenomenon of entrepreneurship has been shown to be highly embedded within a range of social, economic, institutional, spatial, and cultural contexts (Ahl, Berglund, Petterson, \& Tillmar,

(c) The Author(s). 2019 Open Access This article is distributed under the terms of the Creative Commons Attribution 4.0 International License (http://creativecommons.org/licenses/by/4.0/), which permits unrestricted use, distribution, and reproduction in any medium, provided you give appropriate credit to the original author(s) and the source, provide a link to the Creative Commons license, and indicate if changes were made. 
2016; Ama, Mangadi, \& Ama, 2014; Amorós, Borraz, \& Veiga, 2009; Cini, Cucllari, \& Gushi, 2014; Griffiths, Gundry, \& Kickul, 2013; Naguib \& Jamali, 2015), and contextualizing entrepreneurship contributes to our understanding of when, how, and why this activity occurs and who becomes involved in it (Welter, 2011). Based on the much-cited work of Ahl (2006), Hughes, Jennings, Brush, Carter, and Welter (2012) argues that new studies should expand the research beyond the individual entrepreneur to include the contextual variables associated with women's entrepreneurship. This is especially important because 'women's employment choices are more sensitive to the local environment than those of men' (Minniti, 2010, p. 297).

Furthermore, the vast majority of research on women entrepreneurs is still very western-oriented and is derived from research conducted in high-income economies (Brush \& Cooper, 2012; Yadav \& Unni, 2016). Understanding the specific underlying context of women's entrepreneurial activity is a topic of great significance (Yousafzai et al., 2015). While we know that female entrepreneurship differs from country to country (Poggesi, Michela, \& De Vita, 2016), yet there are relatively few studies that inform us on this topic.

Therefore, our research paper focuses on examining the role of specific contextual factors in affecting the propensity of women's entrepreneurial activity in countries that are at different levels of economic development. The contribution this paper makes to the literature is twofold. First, it expands the research on women's entrepreneurship beyond investigations at the individual level. It illustrates how a contextualized view of entrepreneurship contributes to our understanding of entrepreneurial activity, as the context in which entrepreneurs operate provides them with both opportunities for establishing and growing businesses and set boundaries that pose restrictions on their actions (Welter, 2011). Second, this research explores if women's entrepreneurship occurs differently across countries that are at different levels of economic development. In doing so, this paper contributes to the field of international women's entrepreneurship.

\section{Literature review and hypothesis development}

The institutional theory has served as a useful lens to conduct research in entrepreneurship (Bruton, Ahlstrom, \& Li, 2010; Veciana \& Urbano, 2008). Institutions are the humanly devised constraints that structure human interaction. They are made up of formal constraints (e.g., rules, laws, constitutions) as well as of informal constraints (e.g., norms of behavior, conventions, self-imposed codes of conduct). Together, they define the incentive structure of societies and specifically economies (North, 1994). Thereby, the level of entrepreneurship that develops in a society might be explained by the direct action of governments in constructing and maintaining an environment supportive of entrepreneurship as well as by societal norms toward entrepreneurship (Bruton et al., 2010).

Economic development and its influence on entrepreneurial activity is affected by formal and informal institutions. As Acs (2006) argues, three major stages of development can be distinguished in a country, within the context of the global economy. In the first stage, a country's economy is characterized by high rates of non-agricultural self-employment as sole proprietorships account for most small manufacturing firms and service firms. In the second stage, decreasing rates of self-employment occur as individuals find they can earn more money when working for larger firms. In the third stage, the economy is characterized by an increase in entrepreneurial activity as the firm size distribution in developed countries shifts away from larger corporations toward entrepreneurial 
activity (Carree, van Stel, Thurik, \& Wennekers, 2002). There are three reasons for the rise in entrepreneurial activity in the final stage of economic activity: (1) the decrease in the share of manufacturing toward smaller service firms that provide more opportunities for entrepreneurship, (2) improvements in information technologies, and (3) a higher elasticity of substitution, which leads to a higher level of development and more entrepreneurship (Acs, 2006; Aquilina, Klump, \& Pietrobelli, 2006). According to Acs (2006), these arguments describe the presence of a U-shaped relationship between these two concepts. At low levels of economic development, self-employment provides job opportunities and scope for the creation of new markets. In economies in the early or middle stages of economic development, entrepreneurial activity is found to be negatively related to economic development, since most people are trying to move from self-employment to wage employment. In developed economies, one would expect entrepreneurial activity to be positively related to economic development. This is because more individuals have the resources to go into business for themselves, thereby shifting from wage work to entrepreneurial activity.

In a study that examined individuals from 34 nations with different levels of GDP per capita, Minniti (2010) found that the differences in the participation of men and women in the creation of new businesses tended to be $50 \%$ higher for men than for women. The study also shows that the level of male entrepreneurial activity was higher than that of women across all national levels of GDP per capita (a difference of 33\% within high-income countries, $75 \%$ within middle-income countries, and $41 \%$ within low-income countries). These results suggest that male and female entrepreneurial activity is associated with a set of universal factors that equally influence their decisions to start a business. However, these results also indicate that men have higher entrepreneurial propensity rates than women. Also, the differences between the level of male and female entrepreneurial activity was greater in middle-income and low-income countries than in high-income countries, implying that factors do not influence both genders in the same way or with the same intensity (Minniti, 2010). Therefore, examining factors that affect women entrepreneurship in countries with varying levels of economic development will contribute to our understanding.

Researchers have conducted some early examination on the effect of social factors such as corruption and safety (e.g., Breen, Gillanders, McNulty, \& Sizuki, 2015; Matti \& Ross, 2016; Trentini \& Koparanova, 2013), access to education (e.g. Kyler, Nielsen, \& Evald, 2013; Naguib \& Jamali, 2015), and the age dependency ratio (e.g., Mirzaie, 2015; Vijayakumar, 2013) on women entrepreneurship. Considering that the existence of (or lack of) certain institutional factors, e.g., financial access or availability of capital, might affect the rate and size of new venture creation (Bruton et al., 2010), factors such as firm age and firm size (Manolova, Brush, Edelman, \& Shaver, 2012; Nwoye, 2007) are important factors to analyze for their influence on the propensity of women business ownership. Therefore, additional research to examine how social and firm-specific factors influence women entrepreneurship across different economic contexts has the potential to contribute to theoretical underpinnings.

In order to address the effects of institutions in a wide set of environments so that theory can be developed for use by other scholars (Bruton et al., 2010), scholars have used institutional theory as a foundation for entrepreneurship studies and have focused on multiple country databases. For our paper, we reviewed the literature on the influence of institutional factors to promote entrepreneurship and used data collected by World Bank for the period 2012-2014 with information about a broad range of country's social and economic 
characteristics as well as the propensity of women business ownership to develop a set of hypothesis to examine factors that influence women's decisions to start and grow their own businesses. Among the social factors we examine are corruption and safety. Since institutions matter in economic development (North, 1994) and the level of GDP per capita influences the level and type of women entrepreneurship (Minniti, 2010), our paper distinguishes between low-, middle-, and high-income countries (e.g., Brush \& Cooper, 2012; Minniti \& Naudè, 2010) and it includes a total of 59 countries in Africa, the Middle East, Europe, and Asia.

The next section specifically focuses on the effect of social factors on the propensity of women entrepreneurship in countries with different levels of economic development.

\section{Social factors: corruption and safety}

United Nations Convention Against Corruption (United Nations, 2004) identifies and describes the specific conducts that are generally classified as corrupt. They include bribery, embezzlement, theft and fraud, extortion, abuse of discretion, favoritism and nepotism, creating or exploiting conflicts of interest, and improper political donations. The literature finds some evidence of a negative relationship between levels of corruption and entrepreneurship. However, the differential impact of corruption on women entrepreneurs is unknown (Trentini \& Koparanova, 2013).

In general, research indicates that women are better corruption fighters than men (Wilhelm \& Wilhelm, 2011). Studies that use data obtained from both government and private sources have found that women are less likely to engage in corruption than men. For example, Dollar, Fisman, and Gatti (2001) found that higher rates of female participation in parliament are associated with lower levels of corruption. Swamy, Knack, Lee, and Azfar (2001) conducted a research at both the individual and national level and found that, at the micro-level, women are less involved in bribery; at the macro level, a greater participation by women in paid work, in both the private and public sector, is associated with lower levels of corruption. However, both studies have been challenged by other investigations that take into account ideological and cultural approaches and consider that the observed relationship between gender and corruption is mainly caused by the context (Michailova \& Melnykovska, 2009). The same results are supported in other studies that consider a specific sample of countries that share common cultural and ideological legacies. For example, Michailova and Melnykovska (2009) chose a group of 28 former communist and USSR countries and found a relationship between the high number of women in parliament and the low level of corruption.

More recent studies also suggest that women are associated with less corruption in the business world. Trentini and Koparanova (2013) found that, in female-owned firms, there is a significantly lower propensity to bribe than in male-owned firms. However, the results differ when considering gender behavior and different firm sizes. According to the authors, women in micro firms (those employing less than ten employees) have a significantly lower propensity to bribe while, for larger firms, this difference does not exist and, in some cases, women show more propensity toward informal payments than men do. At the same time, women are less likely to engage in tax evasion, thereby showing lower risk propensities. Breen et al. (2015) found that women-owned firms tend to pay smaller bribes and are less likely to use bribery in the first place. Research by Cumming, Leung, 
and Rui (2015), which has examined the effect of board directors' gender diversity on securities fraud, reinforces the link between the presence of women on corporate boards and reduced frequency and severity of corporate fraud.

The literature suggests one to look at per capita income and education as causes of corruption (Svenson, 2005). Ali (2003) found that 'countries with high levels of economic growth are characterized by high levels of judicial efficiency, low levels of corruption, effective bureaucracy, and protected private property'. Tonoyan, Strohmeyer, Habib, and Perlitz (2010) and Breen et al. (2015) also found that a higher GDP is linked to lower incidences of corruption. According to Tonoyan et al. (2010), the likelihood of engaging in corruption is influenced by the lower efficiency of financial and legal institutions and the lack of law enforcement, particularly within transitional economies compared to industrialized countries in Western Europe and North America.

Given the lower propensity for women to tolerate corruption, one can expect that, in contexts where there is less demand for transparency and justice, women will be less likely to venture into the business scene. This leads to the following hypothesis:

Hypothesis 1: The higher the corruption and bribery in low- and middle-incomes countries, the less likely women will be to own equity in firms.

\section{Social factors: safety}

Safety conditions surrounding the future of a company might influence the entrepreneurial propensity. 'Crime is likely to distort both the existence of entrepreneurial opportunities and the entrepreneur's decision to exploit an opportunity' (Matti \& Ross, 2016, p. 256). As the authors argue, crime not only affects the direct and indirect costs of doing business in an area, it additionally creates uncertainty and, thereby, affects opportunity costs, since entrepreneurs cannot perfectly predict how they will be affected by crime. The high opportunity costs associated with crime reduces the likelihood that an individual will exploit an entrepreneurial opportunity (Matti \& Ross, 2016).

In terms of female entrepreneurship and crime, research suggests that crime against firms might be gender-biased in that firms with a female presence at the upper level of the decision-making process may be preferred targets for criminal activity (Islam, 2013). In a subsequent study, Islam (2014) found that economic growth might reduce crime in developing countries. Findings from this study demonstrate that a $1 \%$ increase in growth of real GDP per capita is associated with a $0.30 \%$ reduction in losses due to crime for firms of all sizes. Additionally, this study finds that even though economic growth is associated with a reduction in losses due to crime, the magnitude of this association is larger if the firm has a female owner. Due to the lower impact of losses from crime in firms owned by women, as the GDP per capita grows, we examine the following hypothesis:

Hypothesis 2: The lower the impact of losses from crime in high-income countries, the more likely women are to own equity in firms.

\section{Social factors: access to education}

Education is 'fundamental to the broader notion of expanded human capabilities that lie at the heart of the meaning of development' (Todaro \& Smith, 2012, p. 359). Education 'will have a positive influence on individual self-efficacy and self-confidence, thereby increasing the chances these individuals will not only start businesses, but also have the ability to 
navigate competitive and changing business environments' (Kelly et al., 2015, p. 30). Educational attainment is positively correlated with women's self-employment (Kyler et al., 2013; Naguib \& Jamali, 2015), gender empowerment (Wilhelm \& Wilhelm, 2011), and sustainable development (Shah \& Saurabh, 2015). In a review of empirical research that links general education to selection into entrepreneurship, Dickson, Solomon, and Weaver (2008) found that the higher the average education level in a country, the higher the rates of selection into entrepreneurship. They also found no significant differences in the impact of education on selection based on gender. According to Kelly et al. (2015) (authors of a Global Entrepreneurship Monitor (GEM), Women's Entrepreneurship Special Report), GEM reports consistently show that entrepreneurs have higher levels of education than non-entrepreneurs. The authors mention the findings from the Goldman Sachs 10,000 Women initiative, which shows that training and education do make a difference for women in less-developed economies. Amin and Islam (2015) found that higher the access to education for women in a developing country, the more likely it is to find women as top managers of firms. As the authors argue, 'access to education is more likely to play a key role in developing economies than in developed economies, since access to education is not as big an obstacle for women in developed economies' (Amin \& Islam, 2015, p. 3). 'Education plays a key role in the ability of a developing country to absorb modern technology and to develop the capacity for self-sustaining growth and development' (Todaro \& Smith, 2012, p. 359). Based on the above, this study proposes that the relationship between women's access to education and their ownership in businesses may be conditional on the country's income level. This leads to the following hypothesis:

Hypothesis 3. The greater the access to education for females in low- and middle-income countries, the more likely women are to own equity in firms.

\section{Social factors: age dependency ratio}

For women entrepreneurs, family embeddedness will directly influence how the entrepreneurial process unfolds. Therefore, a holistic understanding of women's entrepreneurship requires including household/family variables in the analysis (Brush, De Bruin, \& Welter, 2009). As noted by the 'gender role perspective' research, 'women are still expected to be the primary nurturer and caregiver in the family, giving priority to serving the needs of any dependents. As such, time allocated to the business is likely to be perceived as incongruent with these role expectations' (Jennings \& McDougald, 2007, p. 52). Further, these authors argue that it is expected that this greater level of family responsibility will lead to greater work-family conflict for female business owners, but not necessarily for male business owners. This has negative implications for female-owned business because it is expected that they will be more likely than male business owners to make accommodations within the work sphere rather than within the family sphere (Jennings \& McDougald, 2007). 'Family responsibility level is typically operationalized by the number of dependents living in an individual's household' (Jennings \& McDougald, 2007, p. 752).

The age dependency ratio refers to the number of children aged 0 to 14 years plus the number of persons aged 65 years or over per 100 persons of working age (those aged between 15 and 64 years). ${ }^{1}$ The dependency ratio can be disaggregated into the following: (1) the youth dependency ratio, which is the number of children aged 0-14 per 100 persons aged 15-64, and (2) the old-age dependency ratio, which is the number of persons 
aged 65 or over per 100 persons aged 15-64. The dependency ratio, also referred to as the total dependency ratio, is the sum of the youth and old-age dependency ratios. A high dependency ratio indicates that the economically active population and the overall economy face greater burdens in supporting and providing the necessary social services to children and older persons who are often economically dependent. It is assumed that the economically active proportion of the population will need to provide for the non-working population's health, education, pension, and social security benefits, either directly through family support mechanisms or indirectly through taxation.

The report of the Population Division of the Department of Economic and Social Affairs of the United Nations (2013) on the world population shows concerns about the unprecedented trend in population aging. Both developed and developing countries are growing older as are rural and urban populations. However, in most countries, and especially in developing countries, rural areas face a double demographic burden-they have more children and older persons in relation to the numbers in the main working-age groups that are available to provide support for the young and the old. This situation results from the combination of higher fertility in rural areas and the sustained out-migration of working-age adults from rural to urban areas. The total dependency ratio, that is, the sum of the child and the old-age dependency ratios, is higher in rural than in urban areas, by at least 10 percentage points, in all major areas of the world, except Northern America. In Africa, Latin America, and the Caribbean, the rural dependency ratio is higher by over 20 percentage points, due to a high child dependency ratio. The rural areas of Africa, Latin America, and the Caribbean have the highest total dependency ratios, at 92 and 74 dependents per 100 adults of working age, respectively. Asia's total urban dependency ratio is the lowest, at 43 dependents per 100 adults of working age, largely because of the low dependency ratio in China. The old-age dependency ratio is higher in rural than in urban areas in all major areas, except Oceania. Access to basic social and health services also tends to be more limited in rural than in urban areas, and poverty rates are higher (United Nations, 2013).

In a study on females' labor force participation in the Middle East, Mirzaie (2015) finds conflicting results between Iran and Turkey. In Iran, there is an inverse relationship between the age dependency ratio and female labor force participation. According to the author, this can be explained by the role of women as caregivers. As the number of children and/or aging relatives increases, women are obligated to remain at home as opposed to working outside the home. In Turkey, there is a significant positive relationship between the age-dependency growth rate and growth in female labor force participation. This shows that when age dependency increases, a higher number of older women remain in the job market, to support themselves, rather than relying on help from their families. This can be explained by a lower level of welfare assistance to female-headed families and the elderly, in Turkey, compared to Iran. As age dependency increases, women in low-income families must work to support their families.

As the literature suggests, with the increase in the age dependency ratio and the related increase of women's role as caregivers in developing countries, the female labor participation (and ownership in businesses) is expected to be lower. This leads to the following hypothesis: 
Hypothesis 4. The higher the age dependency ratio in low- and middle-income countries, the less likely women are to own equity in firms.

Firm factors: size and age

Evidence points to the fact that many women entrepreneurs stay in business for a long time; however, their businesses remain small (Nwoye, 2007). Financial access for supporting and growing a business is regarded as one of the important challenges faced by women entrepreneurs (Guillén, 2014; Naguib \& Jamali, 2015; Shah \& Saurabh, 2015). The research indicates that the relationship between women entrepreneurs and bankers is mired by gender stereotyping: 'aspiring women entrepreneurs tend to be asked to provide guarantees that lie beyond their existing assets, relationships or track record' Guillén (2014, p. 255). Mijid (2015) found that banks adhere to a stereotypical misperception that women business owners are less capable of repaying a loan than their male counterparts are. As Estrin and Mickiewicz (2011, p. 414) points out, 'entrepreneurship is a social activity that is hampered by gender-based constraints'.

In addition, Naguib and Jamali (2015) found that psychological factors could interfere with women's access to capital. In their study on female entrepreneurship in the United Arab Emirates, Naguib and Jamali (2015) found that female entrepreneurs had reservations about taking out loans or disapproved of borrowing money, due to risk aversion, a lack of confidence in their financial capabilities, and a fear of institutional regulations and their mechanisms. These results illustrate the important role of institutional regulative mechanisms and the influence of both a fear of failure and a fear of the process in enabling or constraining female entrepreneurship (Naguib \& Jamali, 2015). Noguera, Alvarez, and Urbano (2013) found similar results in a study on female entrepreneurial activity in Catalonia (Spain).

Women's goals seem to be another reason to explain the size of their businesses. Jennings and Brush (2013) show that women entrepreneurs pursue goals beyond economic gain. One set of research has demonstrated that female entrepreneurs tend to attach less value to business expansion and financial success than their male counterparts do. Research points to 'hybrid' goals, those that are both economic and non-economic in nature that women entrepreneurs pursue (Jennings \& Brush, 2013, p. 693).

Additional reasons for the new venture to remain small or stay in business might be found in the country's stage of economic development. As Minniti (2010) points out, the level of a country's per capita GDP influences the level and type of female entrepreneurial activity. Minniti's findings show that the presence of women entrepreneurs is more significant in countries with lower and higher per capita GDP. In the case of poorer countries, entrepreneurship is often a way out of poverty; in the case of wealthier countries, women are able to take advantage of unexploited opportunities. So, a nation's level of economic development may explain why women are being pushed rather than pulled into an entrepreneurial career. And as Morris, Miyasaki, Watters, and Coombes (2006) suggest, women entrepreneur who are pulled by the recognition of opportunity are significantly more growth-oriented that those who are pushed into entrepreneurship by necessity. According to the 
authors, growth oriented entrepreneurs demonstrate a more visceral identification with their business, and conceive it as an investment whose value need to be continually enhanced. They perceive less conflict between the venture and other life responsibilities and view the external environment in terms of opportunities. Women entrepreneurs who are pushed into entrepreneurship by necessity show a more modest growth orientation and although the new venture may be a source of pride, it is also viewed as an obligation that carries a burden that must be balanced against other life considerations. These women are more focus within the business than on external opportunities, and feel more alone as a business owner. These and other factors explained above, such as financial obstacles or the fears and goals of the entrepreneur, are a challenge for all women entrepreneurs to survive and growth their business. This is especially so in developing countries, where the exit rates of new women-owned businesses are higher, on average, than those of new businesses globally (Vossenberg, 2013).

As was argued above, on the one hand, financial access and the subjective characteristics of women entrepreneurs are factors that influence female businesses to remain small; and this might be even more likely in the national context where income levels are lower. On the other hand, women motives and identity with their businesses result in their exploiting new opportunities, which might influence the higher rate of permanency of female enterprises in higher income countries. Thus, the following hypotheses are proposed:

Hypothesis 5. The smaller the firm size is, in low- and middle-income countries, the more likely women are to own equity in firms.

Hypothesis 6. The more established firms are, in high-income countries, the more likely women are to own equity in firms.

\section{Methodology}

The aim of our hypotheses is to explore contextual variables that influence the propensity of women's business ownership and whether these variables are significantly different, depending on the macroeconomic context. Since the level of GDP per capita influences the level and type of women entrepreneurship (Minniti, 2010), it is important to distinguish between low-, middle-, and high-income countries (see Table 1). In order to generalize our findings, a high number of observations are required. Country databases rarely contain both macro and microeconomic factors on female participation (Langowitz \& Minniti, 2007). For these reasons, we combined both data from the Enterprise Surveys ${ }^{2}$ and World Factbook. The Enterprise Survey is a firm-level survey conducted by the World Bank in the manufacturing and service industries of a private economy. The information is gathered through face-to-face interviews with top managers and business owners in over 130,000 companies, in 125 countries. The surveys include different business topics, including access to finance, taxation, corruption, infrastructure, crime, competition, government relation, and performance measures. Enterprise Surveys uses the Global methodology or standardized data as opposed to country data. Country data includes all questions about a specific country, which may or may not be the same in other country surveys. Standardized data is country data that has been matched to a standard set 
Table 1 List of countries

\begin{tabular}{|c|c|c|c|}
\hline \multirow{2}{*}{$\begin{array}{l}\text { High income } \\
\text { Croatia }\end{array}$} & \multicolumn{2}{|l|}{ Middle income } & \multirow{2}{*}{$\begin{array}{l}\text { Low income } \\
\text { Bangladesh }\end{array}$} \\
\hline & Armenia & Nigeria & \\
\hline Czech Republic & Lebanon & Ghana & Burundi \\
\hline Estonia & Azerbaijan & Pakistan & Cambodia \\
\hline Israel & Macedonia & Hungary & Congo, Dem. Rep. \\
\hline Latvia & FYR & Romania & Kenya \\
\hline Lithuania & Belarus & India & Kyrgyz Republic \\
\hline Poland & Mauritania & Senegal & Lao PDR \\
\hline Russian Federation & Bosnia and & Jordan & Madagascar \\
\hline Slovak Republic & Herzegovina & Serbia & Malawi \\
\hline Slovenia & Moldova & Kazakhstan & Myanmar \\
\hline \multirow[t]{10}{*}{ Sweden } & Bulgaria & Sudan & Nepal \\
\hline & Mongolia & Tunisia & Tajikistan \\
\hline & China & Turkey & Tanzania \\
\hline & Montenegro & Ukraine & Uganda \\
\hline & Djibouti & Uzbekistan & Yemen, Rep. \\
\hline & Morocco & West Bank and & \\
\hline & Egypt, & Gaza & \\
\hline & Arab Rep. & & \\
\hline & Namibia & & \\
\hline & Georgia & & \\
\hline
\end{tabular}

Source: data from World Bank

of questions, thus allowing for comparative studies across countries and survey years. This methodology also helps minimize measurement errors. ${ }^{3}$ Due to a high proportion of missing data in some countries, we limited our sample period to 2012-2014 and the number of countries to 59 as shown in Table 1. After selecting the 59 countries, we merged the Enterprise Surveys with macroeconomic data from the World Bank and the CIA World Factbook to create a new database.

\section{Variables and analytical technique}

\section{Dependent variable: propensity of women business ownership}

To measure the propensity of women business ownership, a dichotomous variable is used. Firms across the selected countries were asked the question, 'among the owners of the firms, are there any females?' The Enterprise Survey allowed for the creation of a gender indicator that is based on this variable.

According to the OECD (2012, p. 23), 'entrepreneurs are those persons (business owners) who seek to generate value, through the creation or expansion of economic activity, by identifying and exploiting new products, processes or markets'. This definition identifies entrepreneurs by their actions, by the outcomes of their activities, and also by how they perceive their own work. They need to make a personal investment (in terms of time, ideas and resources). Entrepreneurs are business owners, bearing the risk associated with the activity of enterprise. In this study, we rely on this conceptual definition of entrepreneur as business owners, 
and use the gender indicator as a variable to guide the measurement and statistical comparisons across countries.

\section{Explanatory variables}

Table 2 describes the explanatory variables and the items related to each variable.

Table 4 provides summary statistics for variables (See Appendix).

\section{Analytical technique}

Stata software was used to perform an econometric analysis of the factors that could affect the likelihood of women as majority owners in firms. Following prior research that used probit regression models as an estimator to understand women and the gender gap in entrepreneurship (e.g., Driga, Lafuente, \& Vaillant, 2005; Kabir, Markowic, Islam, \& Nikitovic, 2014; Parvin, Rahman, \& Jia, 2012), we used probit regression model to determine the predictor variables of a binary dependent variable, $Y$. Firms are observed across $R$ countries. For each country $r=(1, \ldots, R)$, the number of firms $n_{r}$ is such that the total number of firms $n=\sum_{\mathrm{r}=1}^{R} n_{r}$. The dependent variable, $y_{i}$, represents whether each firm $i=(1, \ldots, n)$ has female ownership. The dichotomous variables are estimated using probit models. In this study, two sets of explanatory variables are analyzed, social (X1) and firm attributes (X3), and their impact on the likelihood of firms to have majority female ownership.

Table 2 Descriptions of explanatory variables

\begin{tabular}{|c|c|c|c|}
\hline & Variables & Item & Description \\
\hline \multirow[t]{4}{*}{ Firm Factors } & Age & car1 & $\begin{array}{l}\text { Age of the firm, based on the year in which the firm } \\
\text { began operations. }\end{array}$ \\
\hline & \multirow[t]{3}{*}{ Size } & S & Small $<20$ \\
\hline & & M & Medium (20-99) \\
\hline & & $L$ & Large (100 and over) \\
\hline \multirow[t]{6}{*}{$\begin{array}{l}\text { Social factors } \\
\text { (at the country } \\
\text { level) }\end{array}$} & Age dependency ratio ${ }^{a}$ & Depen & $\begin{array}{l}\text { Age dependency ratio is the ratio of } \\
\text { dependents-people younger than } 15 \text { or older than } \\
64 \text {-to the working-age population-those ages } 15-64 \\
\text { Data are shown as the proportion of dependents } \\
\text { per } 100 \text { working-age population }\end{array}$ \\
\hline & $\begin{array}{l}\text { School life expectancy } \\
\text { Female (primary to tertiary, } \\
\text { in years) }\end{array}$ & Expecf & $\begin{array}{l}\text { Total number of years of schooling (primary to } \\
\text { tertiary) that a child can expect to receive, assuming } \\
\text { that the probability of his or her being enrolled in } \\
\text { school at any particular future age is equal to the } \\
\text { current enrollment ratio at that age }\end{array}$ \\
\hline & Literacy rate for females $^{a}$ & Litf & $\begin{array}{l}\text { Percentage of females ages } 15 \text { and above who can } \\
\text { both read and write and also understand a short } \\
\text { simple statement about their everyday life }\end{array}$ \\
\hline & \multirow[t]{3}{*}{ Corruption and safety } & corr4 & $\begin{array}{l}\text {-Yes/no firms expected to give gifts to public officials } \\
\text { (to get things done) }\end{array}$ \\
\hline & & graft2 & $\begin{array}{l}\text {-Bribery depth (\% of public transactions where a gift } \\
\text { or informal payment was requested) }\end{array}$ \\
\hline & & crime3 & $\begin{array}{l}\text {-Estimated losses as a result of theft, robbery, and } \\
\text { vandalism against the firm as a percentage of annual } \\
\text { sales }\end{array}$ \\
\hline
\end{tabular}

${ }^{a}$ Data from the World Bank

${ }^{b}$ Data from the CIA World Factbook 
The regression modeling takes the following matrix form:

$$
Y^{*}=\mathrm{X} 1 \beta 1+\mathrm{X} 2 \beta 2+\varepsilon
$$

where $Y$ is equal to 1 , if the latent variable $Y^{*}$ is positive, and $Y$ is equal to 0 , otherwise. The latent variable represents each firm's propensity to have a woman as a majority owner. The error term, $\varepsilon$, follows a normal distribution with a variance set to 1 , whereas $\beta 1, \beta 2$, and $\beta 3$ represent the vectors of the parameters to be estimated. The marginal effect was calculated to estimate the change in the probability for women to own equity in a business. Table 3 reports these estimated coefficients.

\section{Results and analysis}

Columns 2, 3, and 4, in Table 3, show the results for our hypotheses. These columns contain the marginal effects, which means that there is a change in the propensity of a firm to have female ownership when the independent variable increases by 1 unit holding other variables constant at their mean value.

Depending on the developmental level of countries, our findings indicate that the firm and social characteristics have different impacts on women's propensity to own businesses. The estimated coefficients that link women's participation in business to a country's level of corruption and bribery indicate no statistically significant relationship in both high-income and low-income countries. This implies that the very low level of corruption and bribery in wealthier countries, on the one hand, and the very high level of these practices in low-income countries, on the other hand, render them irrelevant with regard to women's business ownership.

Women in middle-income countries are more sensitive to corruption and bribery, since countries in this category are either emerging economies or are in the transition phase between developing and developed economies. Interestingly, an increase of one unit in the degree of bribery decreases the likelihood of women owning equity in firms. The corruption indicator is based on the percentage of firms that were not expected to give gifts to public officials; thus, the negative sign should be carefully interpreted. A

Table 3 Probit regression

\begin{tabular}{llll}
\hline Independent variables & High income & Middle income & Low income \\
\hline Firm factors & $.00403^{* * *}(0.000)$ & $0.00161^{* * *}(0.000)$ & $0.0018^{* * *}(0.012)$ \\
Age & $0.0593^{* * *}(0.000)$ & $-0.0295^{* *}(0.046)$ & $-0.0365(0.390)$ \\
Small business & & & \\
Social factors & $-0.0048^{* *}(0.047)$ & $-0.00429(0.168)$ & $0.002^{* * *}(0.006)$ \\
Age dependency ratio & $0.0305^{* *}(0.049)$ & $0.0194(0.123)$ & $0.3053^{* * *}(0.000)$ \\
School life expectancy Female & $-0.0001(0.626)$ & $0.0008^{* * *}(0.000)$ & $-0.0000(0.898)$ \\
Corruption & $0.0001(0.804)$ & $-0.0005^{* * *}(0.000)$ & $0.0002(0.361)$ \\
Bribery & $0.0001(0.497)$ & $-0.0001(0.697)$ & $0.0003^{*}(0.06)$ \\
Crime & 0.0108 & 0.0479 & 0.0537 \\
Pseudo $R^{2}$ & -2242.5908 & -9875.6071 & -2693.2441 \\
Log likelihood & $49.16^{* * *}$ & $993.28^{* * *}$ & $305.45^{* * *}$ \\
LR (chi2) & 3571 & 17,498 & 4619 \\
Number of observations & & & \\
\hline
\end{tabular}

$*{ }^{* *}, * * *=$ Significant at the $0.10,0.05$, and 0.01 level, respectively 
one-unit increase in the percentage of firms that are not expected to give gifts to officials increases the probability of women's participation in business by $0.08 \%$. More specifically, women in middle-income countries are less likely to participate in a business that practices corruption. Consequently, we confirm hypothesis 1 for the propensity of women to own equity in a firm in middle-income countries.

In hypothesis 2, we expected that the reduction in losses due to crime for firms in high-income countries would increase the propensity of women to own business. Our results do not support this hypothesis. In fact, as indicated in Table 3, in low-income countries, an increase of 1 unit in the estimated loss from vandalism increases the likelihood of women owing equity in business by $0.03 \%$. This indicates that due to the predominance of crime in low-income countries, women are more likely to own equity even when their estimated loss from vandalism and other crimes is high. This finding is intriguing and needs further research.

Our findings support hypothesis 3 . Level of education is directly correlated with the propensity of women to participate in business equity. This relationship is not dependent on country's development level.

The findings on the age dependency ratio, in high- and low-income countries, indicate a statistically significant propensity for women to own equity in a business at a significance level of 0.05 and 0.01 respectively. This relationship is not significant for middle-income countries. In high-income countries, the age dependency ratio is negatively related to the propensity for women's business ownership. An increase of 1 unit in the age dependency ratio decreases the likelihood of women owning equity in businesses by $0.48 \%$. Women's heavy family responsibilities limit their ability to devote time and energy to entrepreneurial endeavors (Parasuraman, Purohit, Godshalk, \& Beutell, 1996). However, in low-income countries, an increase of 1 unit in the age dependency ratio increases the likelihood of women owning equity in businesses by $0.2 \%$. Therefore, it appears that women who live in lower-income countries, even when they have greater obligations toward their families, are more likely to participate in businesses than women in wealthier countries are, due to the greater deterrent family responsibilities pose to the entrepreneurial activity of this latter group.

Coefficient of interaction between firm size and women's ownership is significant for high- and middle-income countries. In middle-income countries, the coefficient of interaction is negative while it is positive in higher-income countries for small firms which are defined as a business that employs fewer than 20 employees. This means that women in high-income countries are $5.93 \%$ more likely to own smaller firms while women in middle-income countries are $2.9 \%$ less likely to own smaller firms. Therefore, hypothesis 5 is not confirmed. One explanation for this could be that the sample used by the Enterprise Survey only included non-agricultural private formal firms, whereas a large percentage of women entrepreneurs in developing countries contribute to ownership via self-employment (Schneider \& Dominik, 2000). Enterprise Survey provides valuable data to compare the involvement of women in businesses across countries of different development levels; however, this data is not perfect in that it only considers formal firms.

In high-income countries, firm age has a statistically significant positive effect on women's entrepreneurial activity. More specifically, the results show that women in these countries are $0.4 \%$ more likely than men are to own a business for every 
additional year after a company's establishment. In middle-income countries, women are $0.16 \%$ more likely to own a business for every additional year after a company's establishment. In low-income countries, women are $0.18 \%$ more likely than men to own a business for every additional year after a company's establishment. Because high-income countries are at least twice as more likely to own a business as firms become more established, we can confirm hypothesis 6, that women in high-income countries are more likely to own equity in more-established firms.

\section{Conclusions and implications}

This study empirically examines the contextual variables that influence the propensity of women business ownership across countries that are at different stages of economic development. Our analysis includes 59 countries from Africa, the Middle East, Europe, and Asia.

In terms of the social factors, we find that the level of corruption in both high- and low-income countries is irrelevant to women's business ownership. However, women in middle-income countries are more sensitive to corruption. According to our results, women in these countries are less likely to participate in a business that practices corruption. Although not statistically significant, it is worth noting the results on women-owned businesses and corruption in high- and low-income countries. If we consider the predominance of opportunity-based entrepreneurship in high-income countries, then our results are consistent with the suggestion of Bagby, Umble, and Palich (2003), who note that these types of entrepreneurs are able to thrive in any situation, regardless of the level of corruption. The predominance of corruption and bribery in low-income countries has led to the acceptance of corruption within the socio-economic culture. In the lowest-income countries, dealing with corruption and bribery in order to do business might be a necessary evil. Martin, Cullen, Johnson, and Parboteeah (2007) suggest that, in low-income countries, firms that are facing pressure to grow and survive engage in bribery so as to remove any obstacles to achieving their financial goals. The relationship between corruption and female entrepreneurship should require a different approach, since, according to Olken and Pande (2011, p. 12), 'even among countries at similar income levels, and even within countries, there is marked heterogeneity in corruption levels'. In terms of crime, the findings on women-owned businesses and crime in low-income countries is worth noting. This is an unexpected finding, especially since earlier research attests that female presence at the upper level of decision-making process may be preferred targets for criminal activity, and this vulnerability might be a deterrent to women in owning a business. Additional research on relationship between these two variables is certainly warranted.

Regarding women's education and its impact on female entrepreneurship, the results show that the more educated women are more likely to participate in a business's equity, regardless of the developmental level of the country of origin. This finding is consistent with previous research; for example, in a 2012 study on the effect of education on female entrepreneurship in 29 member states of the Global Entrepreneurship Monitor (GEM), Razmi and Firoozabadi (2016) found that the average number of years of schooling has a significant positive correlation with female entrepreneurship. The findings on the age dependency ratio indicate a negative relationship in high- and middle-income countries. However, in low-income countries, the higher the age dependency ratio, the higher is the likelihood of women to own equity in a business. 
Therefore, it seems that women living in lower-income countries, even those who have greater obligations toward their families, are still more likely to participate in a business, compared to women in wealthier countries, where family responsibilities can be more of a deterrent. This finding could be consistent with Williams' (2004) research, which found that, in many of the European countries studied, caring for children has a negative impact on the duration of self-employment. This negative effect suggests that programs designed to encourage female self-employment may be most effective if they are also coordinated with programs that aim to improve childcare opportunities (Williams, 2004). As Vossenberg (2013) points out, more research is needed on the subject of women's coping strategies when combining entrepreneurship with family responsibilities, regardless the country's level of development.

In terms of firm factors, the propensity of women to own equity in more-established firms is higher in high-income countries than in middle- and low-income countries. Women in high-income countries are also more likely to own smaller firms. These findings are interesting to examine in terms of work-life balance. One could suppose that smaller firm sizes would provide women entrepreneurs with more control and less pressure in terms of managing this balance. An alternate explanation is that in several middle- and low-income countries, access to support network through extended family and economically feasible labor may provide an explanation to the differences in women's propensity to own equity across high-income, middle-income, and low-income countries. According to Jennings and McDougald (2007), there are several reasons why women entrepreneurs operate smaller firms. They include a lack of support in both the business and the family, or women entrepreneurs' decisions to postpone expanding their business until their family responsibilities and/or household demands are lower. In fact recent research's results suggest the changing role of family support in continued entrepreneurship with direct family involvement positively moderating the relationship between attitude to growth and growth intentions (Venugopal, 2016). An interesting research question is to examine the role of the ecosystem in facilitating women's entrepreneurship.

One of the most important contributions of our research is the generalization of our results across three different types of economic and social contexts. However, more detailed studies are needed, including those that combine institutional contexts and perceptual factors associated with female entrepreneurship. As Langowitz and Minniti (2007) points out, not everything on women entrepreneurial behavior is explained by context, some behaviors might be the result of specific perceptual factors. In fact, perceptual factors are the long-term outcomes of the institutional settings. Future research could combine contextual and perceptual factors to compare their influence on women entrepreneurial behavior.

While the findings from this study contribute to the literature, there were several limitations in this study. First, both macro and micro variables were used to explain the propensity of female participation in firm ownership. In combining firm-level data with macroeconomic variables available through the World Bank database, there were a large number of observations that were lost through this merging process. The difficulty of finding a cross-country database with both macro and microeconomic factors on female participation was a major limitation on determining our variables. In other words, in an attempt to adopt a contextualized cross-country analysis to study women entrepreneurship, only a few variables that are relevant to female entrepreneurship were available through Enterprise Surveys. We recognize the importance 
of including additional institutional factors that pertain to the country's culture and laws as well as additional firm variables.

Another limitation of our study is the difficulty of developing a comprehensive measurement of women's propensity to entrepreneurship. The dependent variable, propensity of women business ownership estimates the impact of women involvement in the company ownership based on their participation in the ownership and not the amount (or \%) of equity owned. A measurement including the percentage of equity owned in the company would have allowed for a more precise measurement. We are also aware of the fact that owning equity is not equivalent to actively engaging and managing a business. However, we think that the dichotomous variable that we have used in our study is an indicative and not an exact measure to examine the hypotheses in our study. Future research may use different measures to assess the propensity of women business ownership including percentage of equity owned by women.

Although our study includes a high number of countries across different income categories, it does not include major developed countries, such as the USA, Austria, Germany, Canada, etc. Consequently, our high-income category should be interpreted with caution and should not be taken to represent all developed countries.

In conclusion, our research points to some contextual factors that influence entrepreneurial propensity of women across different country contexts. The level of a country's economic development, corruption, and country's level of economic development and education are factors that affect the decisions of women's participation in businesses. The results of this paper point to new areas for future research that can lead to a better understanding of women's contributions to global development. The findings can also serve as a guide to support women's business endeavors since such endeavors could enhance a country's well-being and contribute to social equity (Minniti, 2010).

\section{Endnotes}

${ }^{1}$ Dependency ratio $=100 \times$ (population $(0-14)+$ population $\left.(65+)\right) /$ population (15-64)

${ }^{2}$ More information is available at http://www.enterprisesurveys.org

${ }^{3}$ http://www.enterprisesurveys.org/ /media/GIAWB/EnterpriseSurveys/Documents/ Methodology/Sampling_Note.pdf

\section{Appendix}

Table 4 Summary statistics for all variables

\begin{tabular}{llllll}
\hline Variables & Observations & Mean & Std. Deviation & Min & Max \\
\hline WE & 47,345 & .281318 & .449647 & 0 & 1 \\
Depen & 48,499 & 57.78794 & 16.75868 & 34.551 & 103.3531 \\
Expecf & 48,499 & 12.10949 & 2.665561 & 6 & 18 \\
car1 & 47,228 & 17.03096 & 13.40905 & 1 & 214 \\
S & 4849 & .4700509 & .4991074 & 0 & 1 \\
corr4 & 42,245 & 21.35401 & 40.98105 & 0 & 100 \\
graft2 & 32,419 & 18.1645 & 36.12833 & 0 & 100 \\
crime & 47,004 & .5640254 & 3.460431 & 0 & 100 \\
\hline
\end{tabular}


Acknowledgements

Not applicable.

Availability of data and material

Secondary data was secured from the following data sites:

- CIA World Factbook: https://www.cia.gov/library/publications/the-world-factbook/

- World Bank: https://data.worldbank.org/

- Enterprise surveys: http://www.enterprisesurveys.org

http://www.enterprisesurveys.org/ /media/GIAWB/EnterpriseSurveys/Documents/Methodology/Sampling_Note.pdf

\section{Funding}

Not applicable.

\section{Authors' contributions}

IK developed the methodology and analyzed the data. AMF and RA were major contributors in writing the manuscript. All authors reviewed the manuscript. All authors read and approved the final manuscript.

\section{Competing interests}

The authors declare that they have no competing interests in the manuscript

\section{Publisher's Note}

Springer Nature remains neutral with regard to jurisdictional claims in published maps and institutional affiliations.

\section{Author details}

'Department of Business Management, Faculty of Economics and Business Sciences, University of Granada, Campus Universitario de Cartuja, 18071 Granada, Spain. ${ }^{2}$ Department of Management and Entrepreneurship, Williams College of Business, Xavier University, 3800 Victory Parkway, Cincinnati, OH 45207, USA.

Received: 11 December 2018 Accepted: 3 April 2019

Published online: 03 May 2019

\section{References}

Acs, Z. (2006). How is entrepreneurship good for economic growth? Innovations: Technology, Governance, Globalization, $1(1), 97-107$

Ahl, H. (2006). Why research on women entrepreneurs needs new directions. Entrepreneurship Theory \& Practice, 30(5), 595-621.

Ahl, H., Berglund, K., Petterson, K., \& Tillmar, M. (2016). From feminism to femlnc.ism: On the uneasy relationship between feminism, entrepreneurship and the Nordic welfare state. International Entrepreneurship and Management Journal, 12(2), 369-392.

Ali, A. M. (2003). Institutional differences as sources of growth differences. Atlantic Economic Journal, 31(4), 348-362.

Ama, N. O., Mangadi, K. T., \& Ama, H. A. (2014). Exploring the challenges facing women entrepreneurs in informal crossborder trade in Botswana. Gender in Management: An International Journal, 29(8), 505-522.

Amin, M. \& Islam, A. (2015). Women managers and gender-based gaps in access to education: evidence from firm-level data in developing countries. Policy research working paper 7269. World Bank Group. https://papers.ssrn.com/sol3/papers. cfm?abstract_id=2609176. Accessed 7 Nov 2017.

Amorós, J. E., Borraz, F., \& Veiga, L. (2009). Do socio-economic indicators really matter for entrepreneurship? A Latin-American perspective. In ICSB world conference proceedings (pp. 1-17). Washington: International Council for Small business (ICSB) file:///Users/hp/Downloads/Do_Socio_economic_Indicators_Really_Matters_for_E.pdf. Accessed 7 Nov 2015.

Aquilina, M., Klump, R., \& Pietrobelli, C. (2006). Factor substitution, average firm size and economic growth. Small Business Economics, 26(3), 203-214

Bagby, R., Umble, E., \& Palich, L. E. (2003). Do corrupt practices affect the development of SMEs? Internationales Gewerbearchiv, 51(1), 1-11 http://www.kmu-hsg.ch/rencontres/IGW_Rencontres/BAND2002_WEB/F_01_Ray.pdf, Accessed 9 Dec 2016.

Breen, M., Gillanders, R., McNulty, G. \& Sizuki, A. (2015). Gender and corruption in business. MPRA paper no. 63850, 2015. http://mpra.ub.uni-muenchen.de/63850/. Accesed 15 Feb 2016.

Brush, C. G., Carter, N. M., Gatewood, E. J., Greene, P. G., \& Hart, M. (2006). Growth-oriented women entrepreneurs and their businesses: A global research perspective. Cheltenham: Edward Elgar.

Brush, C. G., \& Cooper, S. Y. (2012). Female entrepreneurship and economic development: An international perspective. Entrepreneurship and Regional Development, 24(1-2), 1-6.

Brush, C. G., De Bruin, A., \& Welter, F. (2009). A gender-aware framework for women's entrepreneurship. International Journal of Gender and Entrepreneurship, 1(1), 8-24.

Bruton, G. D., Ahlstrom, D., \& Li, H.-L. (2010). Institutional theory and entrepreneurship: Where are we now and where do we need to move in the future? Entrepreneurship Theory \& Practice, 34(3), 421-440.

Bullough, A., Renko, M., \& Abdelzaher, D. (2017). Women's business ownership: Operating within the context of institutiona and in-group collectivism. Journal of Management, 43(7), 2037-2064.

Carree, M., van Stel, A., Thurik, R., \& Wennekers, S. (2002). Economic development and business ownership: an analysis using data of 23 OECD countries in the period 1976-1996. Small Business Economics, 19(3), 271-290. 
Cini, M., Cucllari, F., \& Gushi, L. (2014). Problems and challenges facing Albanian women entrepreneurs. In Economic and social development, book of proceedings (pp. 619-626). Vienna: Varazdin Development and Entrepreneurship Agency (VADEA).

Cumming, D., Leung, T. Y., \& Rui, O. (2015). Gender diversity and securities fraud. Academy of Management Journal, 15(5), 1572-1593.

Dickson, P. H., Solomon, G. T., \& Weaver, K. M. (2008). Entrepreneurial selection and success: Does education matter? Journal of Small Business and Enterprise Development, 15(2), 239-258.

Dollar, D., Fisman, R., \& Gatti, R. (2001). Are women really the 'fairer' sex? Corruption and women in government. Journal of Economic Behavior \& Organization, 46(4), 423-429.

Driga, O., Lafuente, E. \& Vaillant, Y. (2005). Gender differences in entrepreneurial activity: An analysis of informal institutional factors. http://www.sbaer.uca.edu/Research/icsb/2005/065.pdf. Accessed 22 Feb 2016.

Estrin, S., \& Mickiewicz, T. (2011). Institutions and female entrepreneurship. Small Business Economics, 37, $397-415$.

Griffiths, M. D., Gundry, L., \& Kickul, J. R. (2013). The socio-political, economic, and cultural determinants of social entrepreneurship activity. An empirical examination. Journal of Small Business and Enterprise Development, 20(2), $341-357$.

Guillén, M. F. (2014). Women entrepreneurs. Inspiring stories from emerging economies and developing countries. New York, NY: Routledge.

Hughes, K. D., Jennings, J. E., Brush, C., Carter, S., \& Welter, F. (2012). Extending women's entrepreneurship research in new directions. Entrepreneurship Theory \& Practice, 36(3), 429-441.

International Labour Organization (2016). Women's entrepreneurship development. wcms_175471.pdf. Accessed 1 Feb 2016.

Islam, A. (2013). Is there a gender bias in crime against firms in developing economics? Women's Studies International Forum, 37, 1-15.

Islam, A. (2014). Economic growth and crime against small and medium sized enterprises in developing economies. Small Business Economics, 43(3), 677-695.

Jennings, J. E., \& Brush, C. G. (2013). Research on women entrepreneurs: Challenges to (and from) the broader entrepreneurship literature? Academy of Management Annals, 7(1), 661-713.

Jennings, J. E., \& McDougald, M. S. (2007). Work-family interface experiences and coping strategies: Implications for entrepreneurship research and practice. Academy of Management Review, 32(3), 747-760.

Kabir, M. S., Markowic, M. R., Islam, M., \& Nikitovic, Z. (2014). Social capital in rural poor women entrepreneurship: The case of Bangladesh. Journal of Advanced Research in Law and Economics, 5(1), 4-14.

Kelly, D., Brush, C. G., Greene, P., Herrington, M., Ali, A. \& Kew, P. (2015). Women's entrepreneurship. Special Report, Global Entrepreneurship Monitor.

Kyler, K., Nielsen, S. L., \& Evald, M. R. (2013). Women's self-employment: An act of institutional (dis) integration? A multi-level, cross-country study. Journal of Business Venturing, 28(4), 474-488.

Langowitz, N., \& Minniti, M. (2007). The entrepreneurial propensity of women. Entrepreneurship Theory \& Practice, 31(3), $341-264$.

Manolova, T. S., Brush, C. G., Edelman, L. F., \& Shaver, K. G. (2012). One size does not fill all: Entrepreneurial expectancies and growth intentions of US women and men nascent entrepreneurs. Entrepreneurship \& Regional Development, 24(1-2), 7-27.

Martin, K. D., Cullen, J. B., Johnson, J. L., \& Parboteeah, K. P. (2007). Deciding to bribe: A cross-level analysis of firm and home country influences on bribery activity. Academy of Management Journal, 50(6), 1401-1422.

Matti, J., \& Ross, A. (2016). Does crime affect entrepreneurship? A discussion of the current literature. Journal of Entrepreneurship and Public Policy, 5(3), 254-272.

Michailova, J. \& Melnykovska, I. (2009). Gender, corruption and sustainable growth in transition countries. MPRA paper no. 17074. http://mpra.ub.uni-muenchen.de/17074/. Accessed 5 Feb 2016.

Mijid, N. (2015). Why are female small business owners in the United States less likely to apply for bank loans than their male counterparts? Journal of Small Business \& Entrepreneurship, 27(2), 229-249.

Minniti, M. (2010). Female entrepreneurship and economic activity. European Journal of Development Research, 22(3), 294-312.

Minniti, M., \& Naudè, W. (2010). What do we know about the patterns and determinants of female entrepreneurship across countries? European Journal of Development Research, 22(3), 277-293.

Mirzaie, I. A. (2015). Females' labor force participation and job opportunities in the Middle East. http://www.Users/hp/ Downloads/FemalesLaborForceParticipationAndJ_preview.pdf. Accessed 6 Jan 2016.

Morris, M. H., Miyasaki, N. N., Watters, C. E., \& Coombes, S. M. (2006). The dilemma of growth: Understanding venture size choices of women entrepreneurs. Journal of Small Business Management, 44(2), 221-244.

Naguib, R., \& Jamali, D. (2015). Female entrepreneurship in the UAE: A multi-level integrative lens. Gender in Management: An International Journal, 3(2), 135-161.

Noguera, M., Alvarez, C., \& Urbano, D. (2013). Socio-cultural factors and female entrepreneurship. International Entrepreneurship and Management Journal, 9(2), 183-197.

North, D. (1994). Economic performance through time. The American Economic Review, 84(3), 359-368.

Nwoye, M. (2007). Gender responsive entrepreneurial economy of Nigeria: Enabling women in a disabling environment. Journal of International Women's Studies, 9(1), 167-175 http://vc.bridgew.edu/jiws/vol9/iss1/10, Accessed 7 Jan 2016.

OECD. (2012). Entrepreneurship at a glance 2012. Paris: OECD Publishing. https://doi.org/10.1787/entrepreneur_aag-2012-en Accessed 1 Feb 2017.

Olken, B. A. \& Pande, R. (2011). Corruption in developing countries. National Bureau of Economic Research Working Papers Series, 2011. http://www.nber.org/papers/w17398.pdf. Accessed: 9 Feb 2016.

Parasuraman, S., Purohit, Y. S., Godshalk, V. M., \& Beutell, N. J. (1996). Work and family variables, entrepreneurial career success, and psychological well-being. Journal of Vocational Behavior, 48(3), 275-300.

Parvin, L., Rahman, W. M., \& Jia, J. (2012). Determinates of women micro-entrepreneurship development: An empirical investigation in rural Bangladesh. International Journal of Economics and Finance, 4(5), 254-260.

Poggesi, S., Michela, M., \& De Vita, L. (2016). What's new in female entrepreneurship research? Answers from the literature. International Entrepreneurship and Management Journal, 12(3), 735-764.

Razmi, M. J., \& Firoozabadi, S. R. (2016). Investigating the effect of education on women's entrepreneurship. International Journal of Learning and Intellectual Capital, 13(2/3), 273-288.

Schneider, F., \& Dominik, E. (2000). Shadow economies: Size, causes, and consequences. Journal of Economic Literature, 38(1), 77-114 
Shah, H., \& Saurabh, P. (2015). Women entrepreneurs in developing nations: Growth and replication strategies and their impact on poverty alleviation. Technology Innovation Management Review, 5(8), 34-43 http://timreview.ca/article/921, Accessed 9 Feb 2016

Svenson, J. (2005). Eight questions about corruption. The Journal of Economic Perspectives, 19(3), 19-42.

Swamy, A., Knack, S., Lee, Y., \& Azfar, O. (2001). Gender and corruption. Journal of Development Economics, 64(1), 25-55.

Terjesen, S., \& Amorós, J. E. (2010). Female entrepreneurship in Latin America and the Caribbean: Characteristics, drivers and relationship to economic development. European Journal of Development Research, 22(3), 313-330.

Todaro, M. P., \& Smith, S. C. (2012). Economic development (11th ed.). Boston: Addison-Wesley.

Tonoyan, V., Strohmeyer, R., Habib, M., \& Perlitz, M. (2010). Corruption and entrepreneurship: How formal and informal institutions shape small firm behavior in transition and mature market economies. Entrepreneurship: Theory and Practice, 34(5), 803-831.

Trentini, C. \& Koparanova, M. (2013). Corruption and entrepreneurship: Does gender matter? United Nations economics Commission for Europe discussion paper series, No. 2013.1, 2013. https://www.unece.org/fileadmin/DAM/oes/disc_ papers/ECE_DP_2013-1.pdf. Accessed 1 Jan 2016.

United Nations (2004). The United Nations Convention Against Corruption, Office on Drugs and Crime. https://www.unodc org/unodc/en/treaties/CAC/. Accessed 1 Jan 2016.

United Nations (2013). World population ageing. Department of Economics and Social Affairs. https://www.un.org/en/ development/desa/population/publications/pdf/ageing/WorldPopulationAgeing2013.pdf. Accessed 1 Jan 2016.

Veciana, J. M., \& Urbano, D. (2008). The institutional approach to entrepreneurship researchlntroduction. International Entrepreneurship and Management Journal, 4(4), 365-379.

Venugopal, V. (2016). Investigating women's intentions for entrepreneurial growth. International Journal of Gender and Entrepreneurship, 8(1), 2-27.

Vijayakumar, S. (2013). An empirical study on the nexus of poverty, GDP growth, dependency ratio and employment in developing countries. Journal of Competitiveness, 5(2), 67-82.

Vossenberg, S. (2013). Women entrepreneurship promotion in developing countries: What explains the gender gap in entrepreneurship and how to close it? Working paper no. 2013/08. Maastricht: Maastricht School of Management http:// web2.msm.nl/RePEc/msm/wpaper/MSM-WP2013-08.pdf, Accessed 3 Dec 2015.

Welter, F. (2011). Contextualizing entrepreneurship-Conceptual challenges and ways forward. Entrepreneurship: Theory \& Practice, 35(1), 165-184.

Welter, F., \& Smallbone, D. (2011). Institutional perspectives on entrepreneurial behavior in challenging environments. Journal of Small Business Management, 49(1), 107-125.

Wilhelm, P. G., \& Wilhelm, J. P. (2011). Gender empowerment, global competitiveness, economic freedom and wealth: Validation studies and implications for sustainable policy. Competition Forum, 9(2), 406-412.

Williams, D. R. (2004). Effects of child-care activities on the duration of self-employment in Europe. Entrepreneurship: Theory and Practice, 28(5), 467-485.

Yadav, V., \& Unni, J. (2016). (2016). Women entrepreneurship: Research, review and future directions. Journal of Global Entrepreneurship Research, 6, 1-18. https://doi.org/10.1186/s40497-016-0055-x.

Yousafzai, S. Y., Saeed, S., \& Muffatto, M. (2015). Institutional theory and contextual embeddedness of women's entrepreneurial leadership: Evidence from 92 countries. Journal of Small Business Management, 53(3), 587-604.

\section{Submit your manuscript to a SpringerOpen ${ }^{\circ}$ journal and benefit from:}

- Convenient online submission

- Rigorous peer review

- Open access: articles freely available online

- High visibility within the field

- Retaining the copyright to your article

Submit your next manuscript at $\boldsymbol{\nabla}$ springeropen.com 